\title{
Flood Vulnerability Analysis using Weighted Overlay
}

\author{
Ferzha Putra Utama ${ }^{1}$, Yudi Setiawan ${ }^{2}$, Arie Vatresia ${ }^{3}$, Julia Purnama Sari ${ }^{4}$ \\ Information System, Engineering Faculty, University of Bengkulu 1, 2, 4 \\ Informatics Engineering, Engineering Faculty, University of Bengkulu ${ }^{3}$ \\ fputama@unib.ac.id ${ }^{1}$, ysetiawan@unib.ac.id ${ }^{2}$, arie.vatresia@unib.ac.id ${ }^{3}$, \\ juliapurnamasari@unib.ac.id ${ }^{4}$
}

\begin{tabular}{l}
\hline \hline Article Info \\
\hline History: \\
Received Jan 1, 2021 \\
Revised Jan 19, 2021 \\
Accepted Sept 1, 2021
\end{tabular}

Keywords:

Flood

GIS

Sungai Serut

Weighted Overlay

\begin{abstract}
Several areas in Bengkulu City are affected by floods every year; one of the worst is the Sungai Serut sub-district. The existence of a river that stretches along Sungai Serut also plays a role in floods over the Bengkulu area. Furthermore, this study to see the priority area over this district is still limited. Mapping flood areas is one way to provide information, especially for decision-makers in flood control using geographic information systems. Our research aims to map flood vulnerability areas based on land height, slope, and river buffer by weighting these criteria. This thematic map is the result of overlaying several maps according to the flood vulnerability criteria. The results of this study indicate that Sungai Serut is an area with "Very Vulnerable" and "Vulnerable" levels of flood vulnerability. The story of flood vulnerability is dominated by gently sloping contours, with land elevation levels mostly below $20 \mathrm{~m}$ above sea level. In addition, the thing that exacerbates the potential for flood vulnerability is the existence of the river that runs along the Sungai Serut sub-district.
\end{abstract}

(C) This work is licensed under a Creative Commons AttributionShareAlike 4.0 International License.

\section{Corresponding Author:}

Ferzha Putra Utama

Information System, Engineering Faculty

University of Bengkulu

Kandang Limun st., Bengkulu, Indonesia, 38371

Email : fputama@unib.ac.id

\section{INTRODUCTION}

Sungai Serut is the sub-district area most severely affected by flooding in Bengkulu city. This shows that every year during the rainy season, it is often affected by floods. This condition can cause much damage to the land, road, and facilities in the area. Theoretically, the flood threat level is equivalent to the height of land above sea level [1], [2]. This area has a reasonably low land elevation. In addition, the characteristics of the flooding that occurs are around the river flow. Floods that occur are caused by elevation and slope factors and often happen because of the overflow of river water in the area [3]. Managing the risk of floods that occur among the vulnerable area is vital to reduce further disasters. This is primarily because the floods that arise in this area keep recurring every year, but most local people are reluctant to evacuate or move to safer places [4]. Regional information can be more easily identified with a map. Mapping flood areas is a way to provide information, especially for decision-makers in optimizing disaster anticipation steps [1]. 
Making maps using tools based on Geographic Information System (GIS) [3], [5] can produce thematic maps in mapping flood vulnerability areas. The mapping of flood vulnerability areas in this study was developed using Quantum GIS [6]. Using the weighted overlay method [7], the spatial data obtained can be given an appropriate weight based on related analysis and research to determine an area against its disaster factors. This data can be used to assess flood vulnerability areas, create evacuation routes in the event of a flood, and provide locations for gathering points and the capacity to accommodate refugees[8], [9].

\section{METHOD}

The research methodology used is non-systematic, a way to use related mapping data that is equipped with supporting maps. This research was carried out in several stages, namely preparation, an implementation which consisted of overlaying the base map used, data processing to calculate values and weights, analyzing the vulnerability class, and finally completing the final map as shown in Figure 1. To conduct this research, it is necessary to prepare the criteria needed and collect the data. Then the next stage is the implementation stage which contains activities to collect data by preparing basic maps, namely administrative maps, land slope maps, land elevation maps, and river distances in Sungai Serut Sub-district, then assigning a weighting to each criterion. The next step is to overlay the base map that has been processed and given weights. After being calculated and analyzed, the final result is a classification of flood vulnerability.

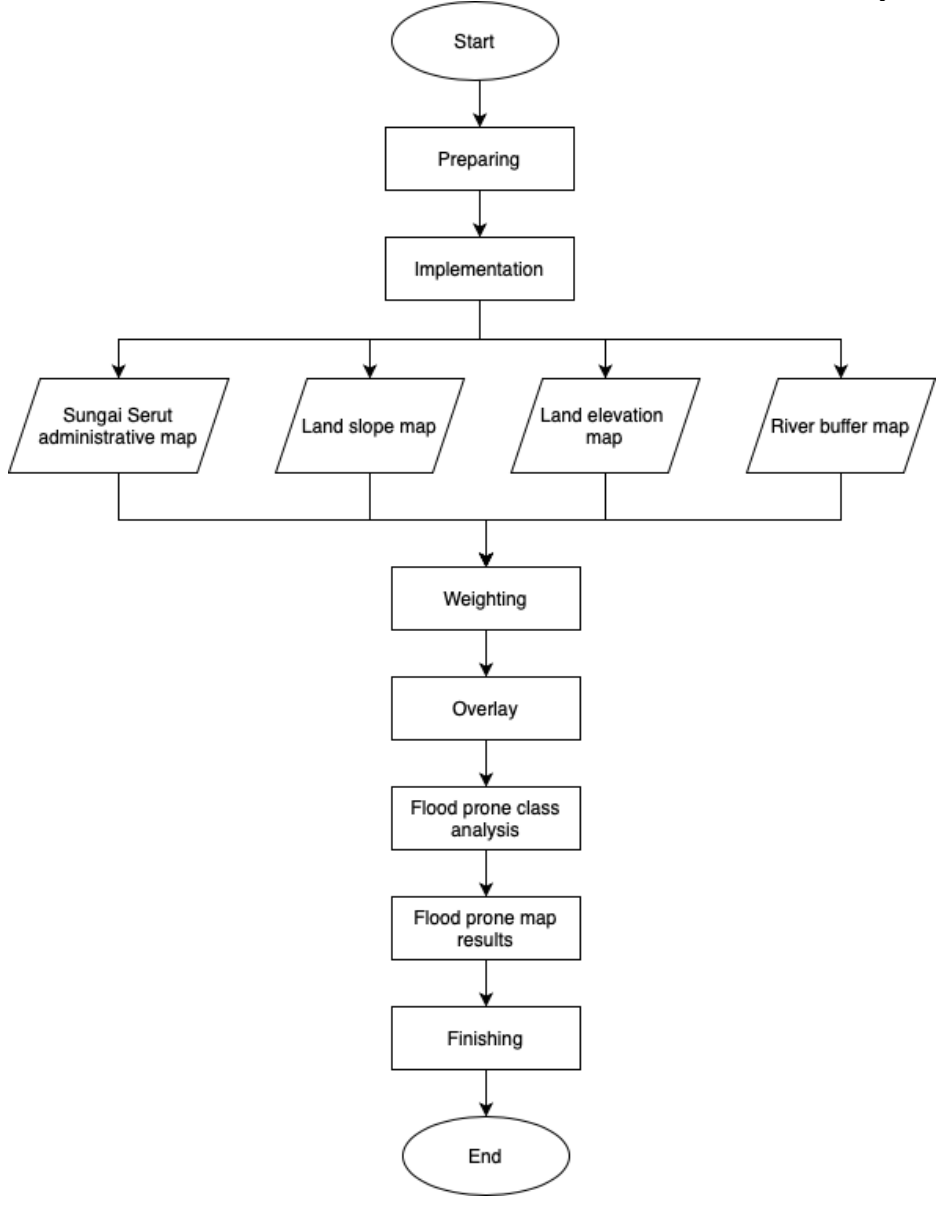

Figure 1. Research Flowchart

\subsection{Data Collecting}

Base maps are maps that become a component processed by specific methods to build a map. The elemental maps that become components in mapping flood vulnerability areas in this study are:

\section{Administrative map}


The administrative map of the Sungai Serut is the main base map used to determine the administrative boundaries of the sub-district. This map provides information only on the Sungai Serut sub-district so that the mapping can be focused only on this area [10].

2. Land slope map

The slope is a visualization of the Earth's surface caused by differences in altitude. The difference in elevation on the slope map can be grouped based on the height value to further contribute to flooding vulnerability. Thus, the gentler the slope, the more potential for flooding, and vice versa. The steeper the hill, the safer it is from flooding [11].

\section{Land elevation map}

Land elevation maps provide information about land elevations and the shape of the Earth's surface in an area. Land elevation maps are usually equipped with contour lines to distinguish the peak of one place from another. The height of the land is, of course, inversely proportional to the potential for flooding; the higher an area is, the less likely it is to be affected by flooding. The site's altitude to sea level is determined from the derivation of the Digital Elevation Model (DEM). The height of the land is then grouped and given a weight value according to the criteria to determine flood vulnerability [12].

\section{River buffer map}

River buffer maps provide information about the coverage of a particular area of the river. The buffer map mechanism provides a border-radius on the desired object (river) to be more comprehensive with a specific value to determine the possibility of overflowing river water, which has a flood impact. [11].

\subsection{Theory}

1. Weighted overlay

A weighted overlay is a method of spatial analysis by overlaying several base maps with certain weights to affect specific vulnerabilities. This method allows solving problems with many criteria to determine a location with a particular potential with digital mapping [7].

\section{Flood vulnerability analysis}

The process of mapping flood vulnerability areas is carried out by preparing a base map that has been downloaded from www.tanahair.indonesia.go.id and processed using Quantum GIS software. After that, the three criteria are weighted. The weighting of the land slope criteria is shown in Table 1.

Table 1. Weight score and classes of slope [13]

\begin{tabular}{clcc}
\hline No & \multicolumn{1}{c}{ Slope classes } & Score & Weight \\
\hline 1. & Flat $(0-4 \%)$ & 5 & \\
2. & Sloping $(4-7,75 \%)$ & 4 & \\
3. & A bit steep $(7,75-11,5 \%)$ & 3 & 35 \\
4. & Steep $(11,5-15,25 \%)$ & 2 & \\
5. & Very steep $(15,25-19 \%)$ & 1 & \\
6. & High-pitched $(>40 \%)$ & 0 & \\
\hline
\end{tabular}

Then give weight to the elevation criteria. The land elevation map is set to differentiate the height every 5 meters, then in the height classification 5 classes are taken as shown in Table 2. 
Table 2. Weight score and classes of elevation [13]

\begin{tabular}{cccc}
\hline No. & Elevation classes (meter) & Score & Weight \\
\hline 1. & $0-10$ & 5 & \\
2. & $11-20$ & 4 & 40 \\
3. & $21-30$ & 3 & \\
4. & $31-40$ & 2 & \\
5. & $>40$ & 1 & \\
\hline
\end{tabular}

River buffer classes are grouped by distance (in meters) namely 0-5, 6-10, 11-15, 1620 and $>20$. This classification is shown in Table 3.

Table 3. Weight score and classes of river buffer [14]

\begin{tabular}{cccc}
\hline No. & River buffer (meter) & Score & Weight \\
\hline 1. & $0-5$ & 5 & \\
2. & $6-10$ & 4 & \\
3. & $11-15$ & 3 & 25 \\
4. & $16-20$ & 2 & \\
5 & $>20$ & 1 & \\
\hline
\end{tabular}

After that, the overlay stage of the three map layers is determined as a flood parameter based on the weight and score values. The result of the overlay will be a new parameter, which is calculated by equation (1) [15].

$$
X=\sum_{i=1}^{n}(W i * X i)
$$

Description:

$\mathrm{X}=$ Vulnerability value

$\mathrm{Wi}=$ Weight for parameter $i$

$\mathrm{Xi}=$ Class score on parameter $i$

From the results of these calculations, an expected value can be determined to give a score to the new map. The vulnerability class in the new map is determined based on the score. The higher the score, the higher the flood vulnerability. The score table for determining the level of flood vulnerability is shown in Table 4.

Table 4. Flood vulnerability score [15]

\begin{tabular}{lll}
\hline No & Vulnerable level & Score \\
\hline 1. & Safe & $<1$ \\
2. & Vulnerable & $3-4$ \\
3. & Very vulnerable & $>4$ \\
\hline
\end{tabular}

\section{RESULTS}

\section{Administrative map}

The administrative map of the Sungai Serut sub-sub-district was obtained from the results of the separation of Sungai Serut from the Bengkulu city map. By using the "select features" menu in QGIS, the sub-district administration map can be selected, as shown in Figure 2. The yellow area is the administrative area of Sungai Serut, while the green one is the Bengkulu city administrative area. 


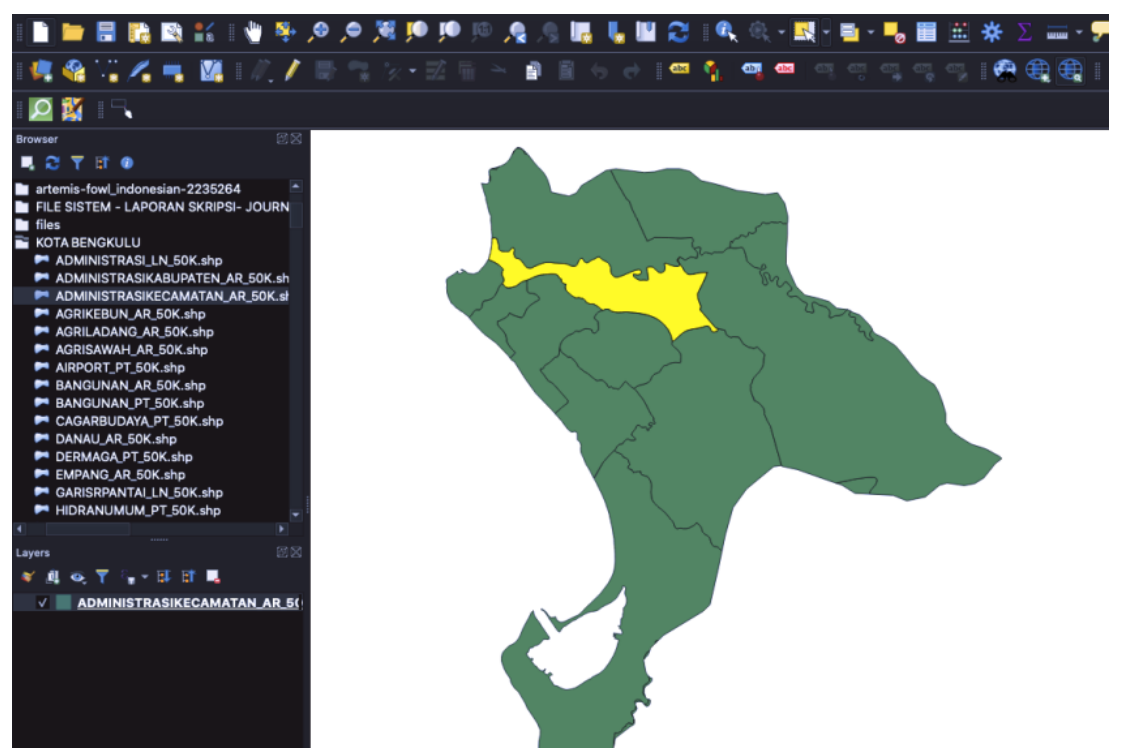

Figure 2. Extraction of administrative map of Sungai Serut sub-district

\section{Land slope map}

The results of this study indicate that the Sungai Serut sub-district has various slopes. However, the most dominant is the slope with a value of 4 to $11.5 \%$, which means it is in the "Sloping" and "A bit steep class". Based on the land slope map, there are areas with 213,300 $\mathrm{m}^{2}$ which are included in the "A bit steep" category, 177,930 $\mathrm{m}^{2}$ in the "Sloping" category, 67,680 $\mathrm{m}^{2}$ in the "Steep" category, and $3,330 \mathrm{~m}^{2}$ in the "Very steep" category. These areas are an accumulation of pixels representing an area with each of $90 \mathrm{~m}^{2}$. Land slope classification in Sungai Serut subdistrict can be shown in Figure 3 and tabularly in Table 5. To make a land slope classification, the properties are set on the DEM map layer by giving a range of height values from 4 to 19 meters according to the classification in Table 1 . The process of land slope classification is shown in Figure 3.

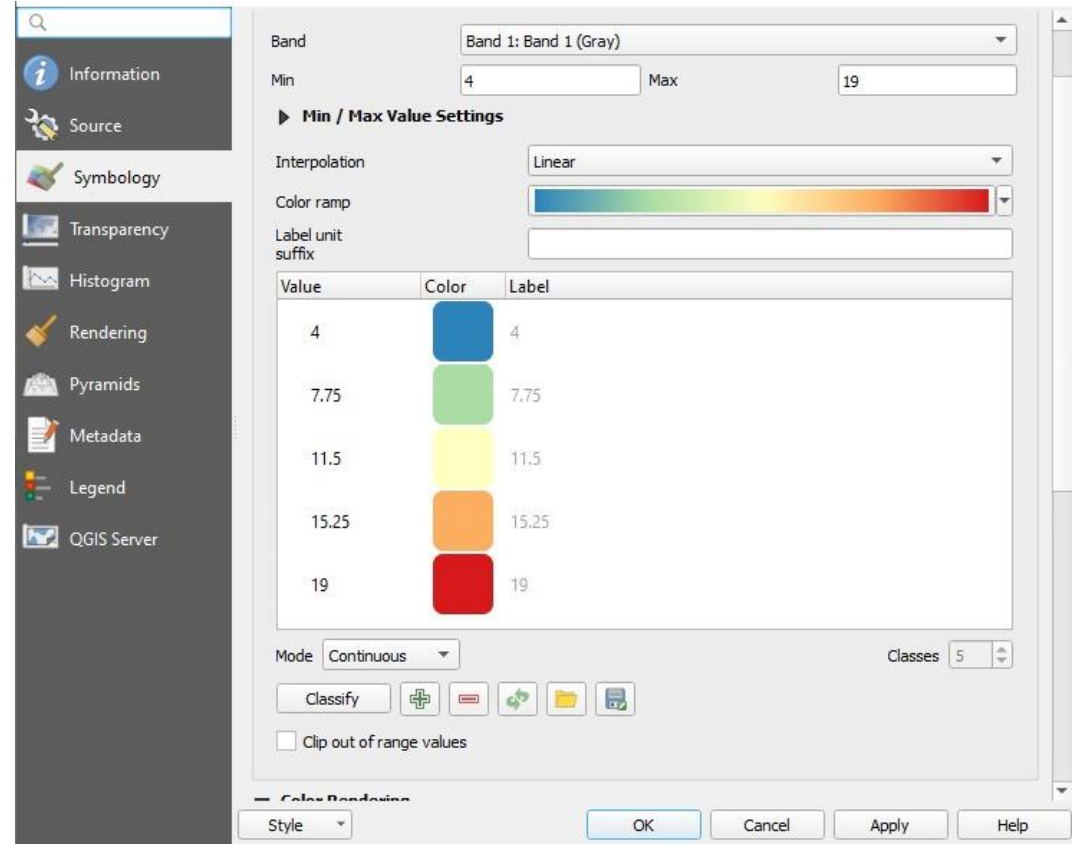

Figure 3. Land slope classification 
Table 5. The data of land slope of Sungai Serut

\begin{tabular}{clccc}
\hline No & \multicolumn{1}{c}{ Land slope classes } & Amount & Pixel color & Area $\left(\mathrm{m}^{2}\right)$ \\
\hline 1. & Flat $(0-4 \%)$ & 4 & & 360 \\
2. & Sloping $(4-7,75 \%)$ & 1977 & & 177.930 \\
3. & A bit steep $(7,75-11,5 \%)$ & 2370 & & 213.300 \\
4. & Steep $(11,5-15,25 \%)$ & 752 & & 67.680 \\
5. & Very steep $(15,25-19 \%)$ & 37 & & 3.330 \\
6. & High-pitched $(>40 \%)$ & 0 & & 0 \\
\hline
\end{tabular}

The result obtained is a map layer of the land slope with a predetermined classification. This map layer is shown in Figure 4.

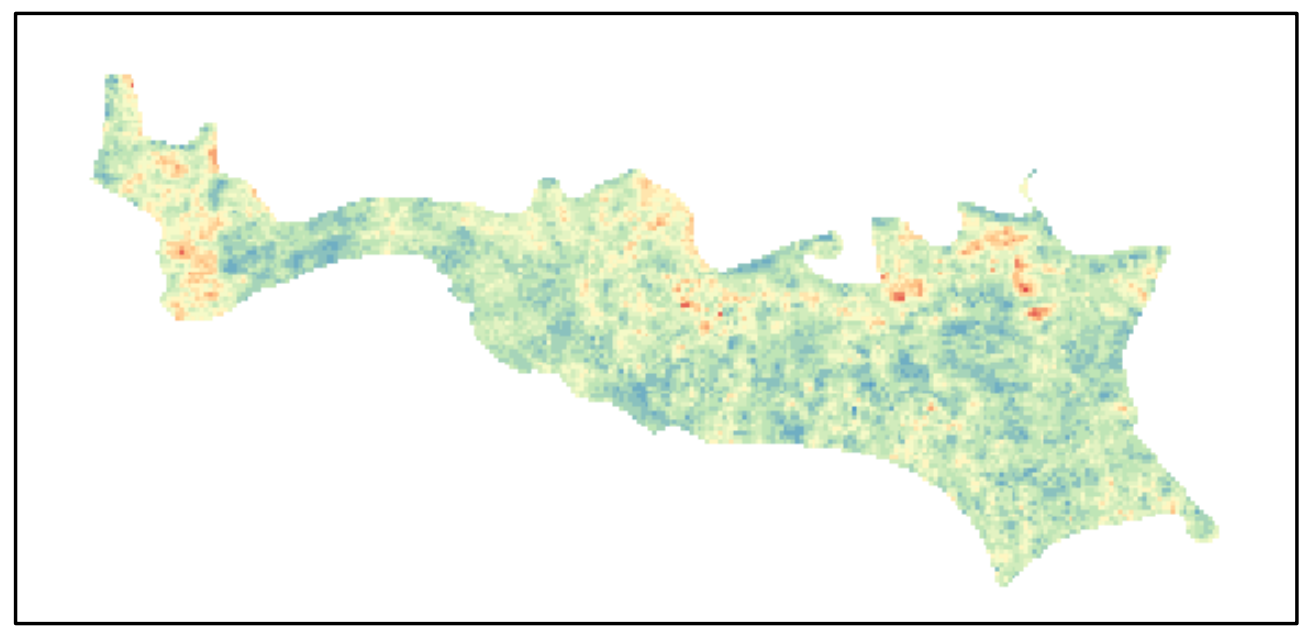

Figure 4. Map of the land slope of Sungai Serut sub-district

\section{Elevation map}

Based on the results of research conducted, the level of land elevation in the Sungai Serut sub-district is mostly at 10 meters. There are 8 areas with a height of 0 meters, 73 regions with a height of $5 \mathrm{~m}, 161$ areas with a height of $10 \mathrm{~m}, 52$ areas with a height of $15 \mathrm{~m}, 30$ areas with a height of $20 \mathrm{~m}$, and 1 area with a height of $25 \mathrm{~m}$. To create a land elevation map layer, a clipping process is carried out on the DEM raster on the administrative map of Sungai Serut District. This layer is extracted by setting the interval based on the height line with a value of 5 , meaning that an area line will separate every 5 meters height. This process is shown in Figure 5. 


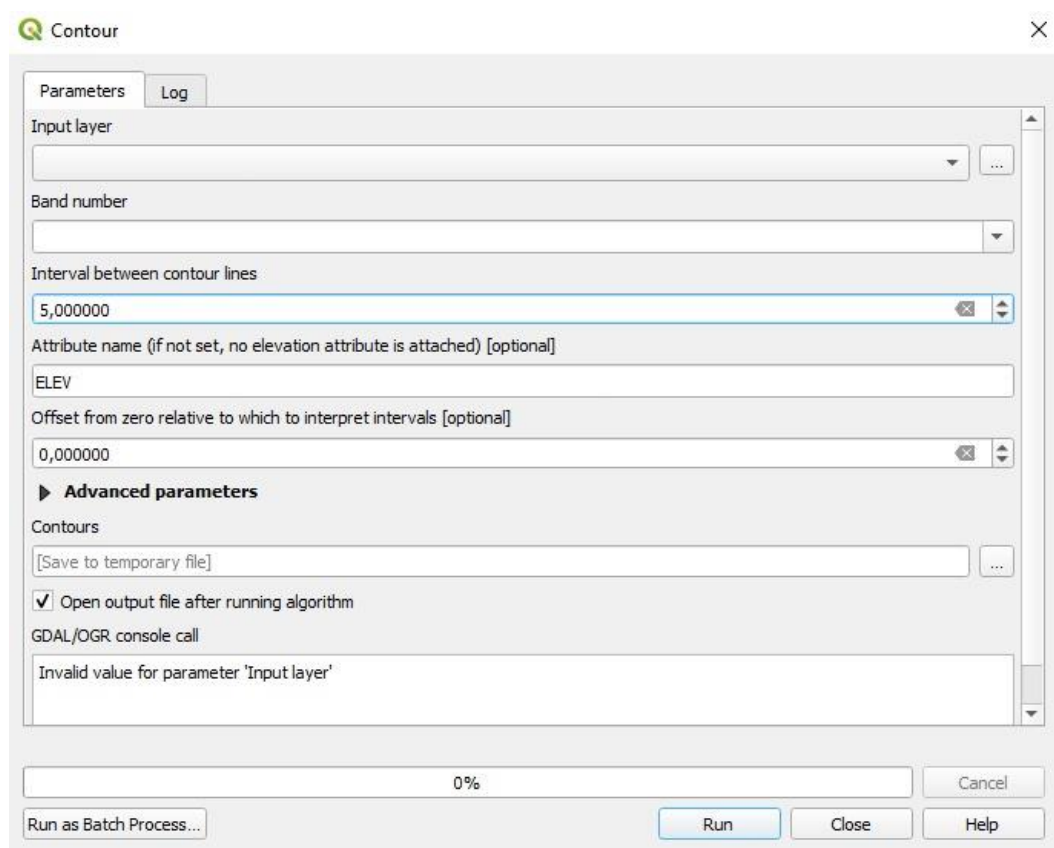

Figure 5. Setting the level of elevation

The next step is to process the contour with the attribute table. Set the elevation line at intervals of 5 to display the difference in height with a thicker line, and this is done with the IF formula (ELEV, $\% 5=0,1$, NULL). The data from this calculation is inputted into a new column called "Kontur," as shown in Figure 6.

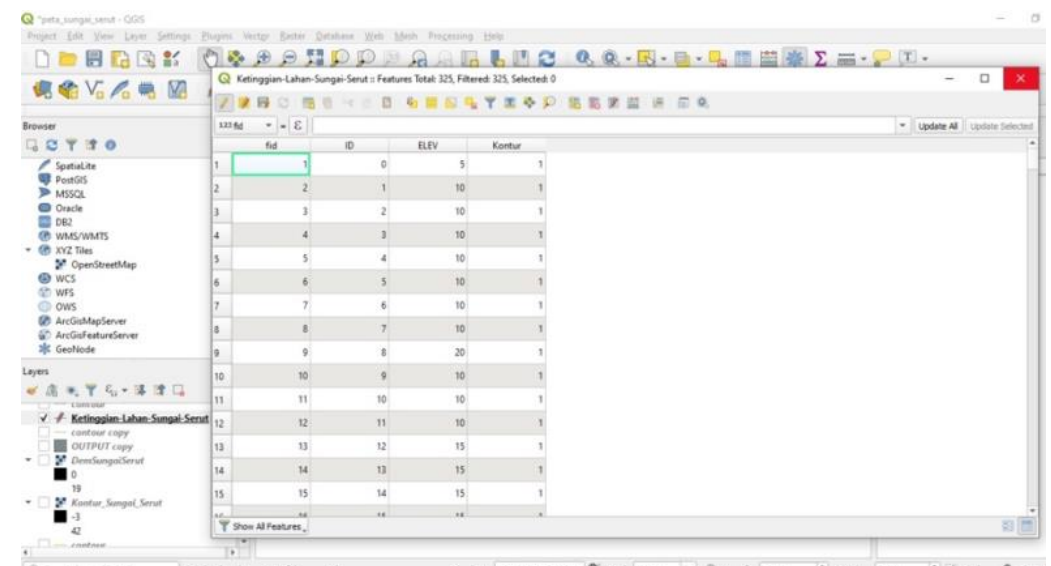

Figure 6. Contour line creation process

To describe the height interval on the contour layer, it can be labeled in the properties section. The values referenced to create the label are the values in the Kontur column. The process of making contour labels is shown in Figure 7. 


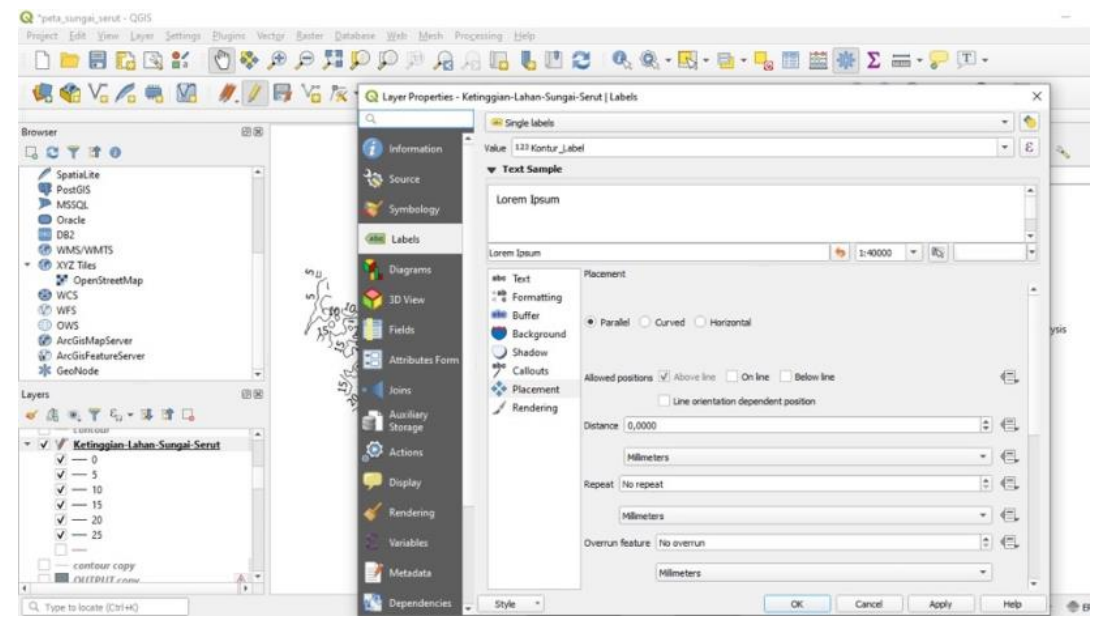

Figure 7. Contour label creation

The land elevation map layer is shown in Figure 8 and presented tabularly in Table 6

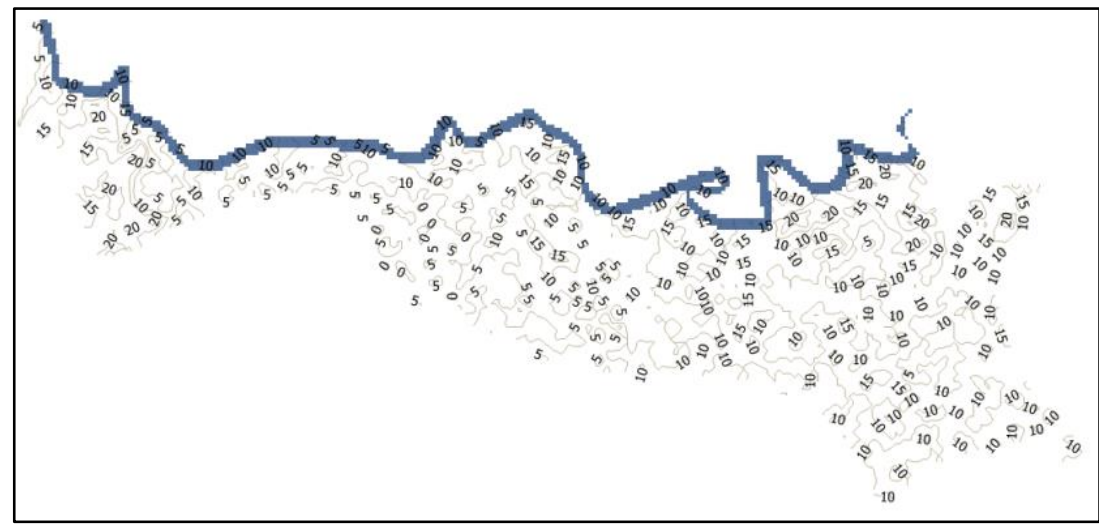

Fig 8. The land elevation map of Sungai Serut sub-district

Table 6. Sungai Serut land elevation classes data

\begin{tabular}{ccc}
\hline No. & Elevation classes (meter) & Amount \\
\hline 1. & $0-10$ & 242 \\
2. & $11-20$ & 82 \\
3. & $21-30$ & 1 \\
4. & $31-40$ & 0 \\
5. & $>40$ & 0 \\
\hline
\end{tabular}

\section{4. $\quad$ River Buffer map}

The river buffer map is the coverage zone or the distance of the river from other areas, which is determined by the distance value. The river buffer is set to a value of 20 meters from the river. In this study, 5 distance classifications were made for river buffers, as shown in Table 7. To create a river buffer map layer, clip the river map according to the administrative map of the Sungai Serut sub-district. After that, buffering is done by giving 5 classifications set on the menu, as shown in Figure 9. 


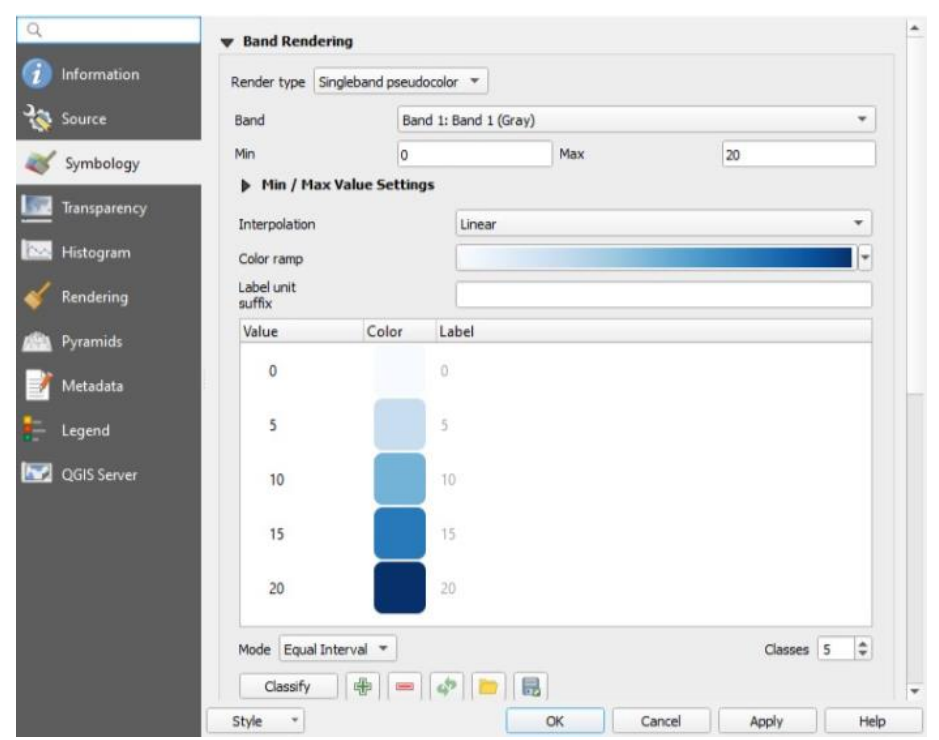

Figure 9. River buffer classification

Based on the data obtained, there is an area of $29,700 \mathrm{~m}^{2}$ which is 6-10 meters from the river, $12,420 \mathrm{~m}^{2}$ of the area with a distance of $11-15 \mathrm{~m}, 900 \mathrm{~m}^{2}$ of the area is $0-5 \mathrm{~m}$, and $270 \mathrm{~m}^{2}$ of the area is $16-20 \mathrm{~m}$ away from the river. The river buffer classification data based on Table 7 is visualized through a layer shown in Figure 10.

Table 7. River buffer classes data of Sungai Serut sub-district

\begin{tabular}{cccc}
\hline No. & River buffer & Amount & Area $\left(\mathrm{m}^{2}\right)$ \\
\hline 1. & $0-5 \mathrm{~m}$ & 10 & 900 \\
2. & $6-10 \mathrm{~m}$ & 330 & 29.700 \\
3. & $11-15 \mathrm{~m}$ & 138 & 12.420 \\
4. & $16-20 \mathrm{~m}$ & 3 & 270 \\
5. & $>20 \mathrm{~m}$ & 0 & 0 \\
\hline
\end{tabular}

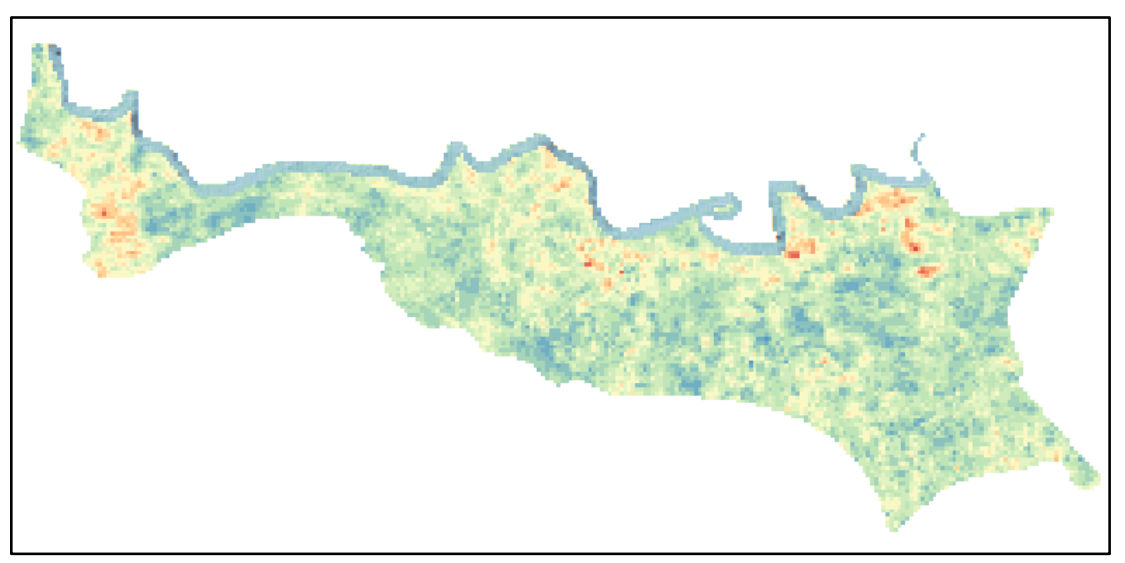

Figure 10. River buffer map

\section{Overlay}

The overlay is done to combine the four map layers that have been compiled in the previous stage to show areas that have the potential for flooding. To overlay, use the intersection feature, which is performed for every 2 map layers. So to be able to overlay the four map layers, 3 intersections were carried out, firstly the administrative map layer and the slope map which became intersection 1, then the land elevation layer and river buffer which became intersection 2, then 
combined both intersections 1 and 2 at intersection 3. One intersection process can be shown in Figure 10.

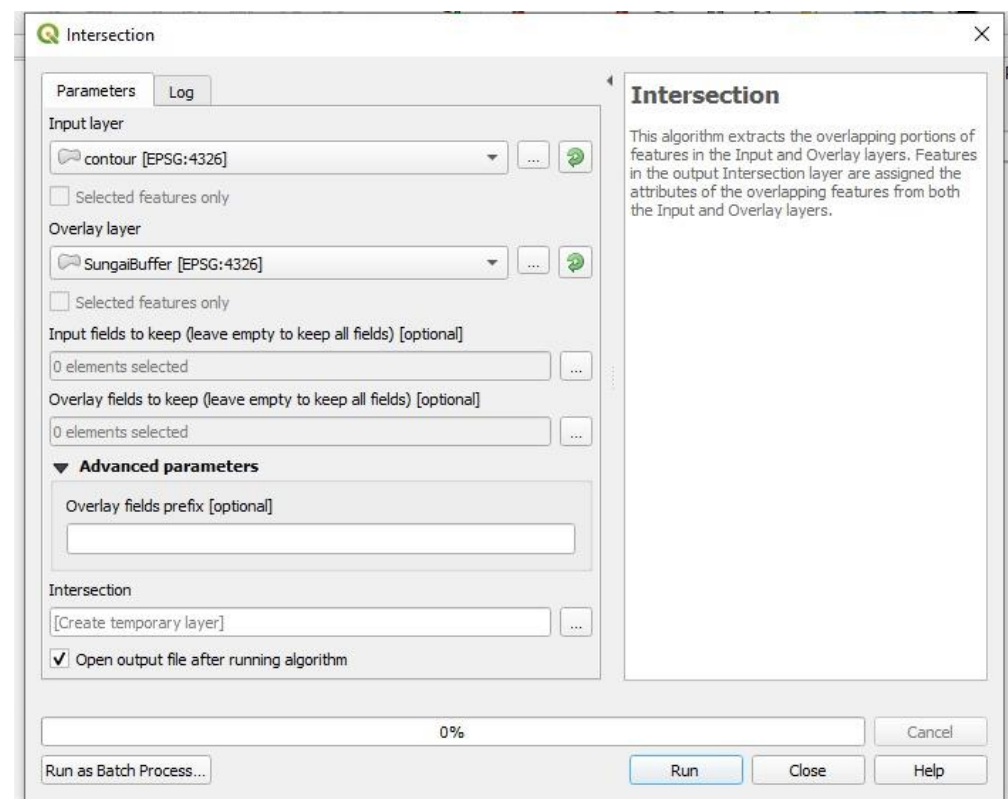

Figure 10. Process of intersection 2 between the land elevation layer and the river buffer layer

Based on the most data from the three categories that determine flood vulnerability, the results are shown in Table 8.

Table 8 . The results of the calculation of scoring and weighting

\begin{tabular}{cccccccccccc}
\hline & Data amount & \multicolumn{9}{c}{ Score } & \multicolumn{3}{c}{ Weight } & Total & $\begin{array}{c}\text { Vulnerable } \\
\text { class }\end{array}$ \\
\hline Slope & Elevation & Buffer & Slope & Elevation & Buffer & Slope & Elevation & Buffer & & Very \\
\hline 2370 & 242 & 330 & 3 & 5 & 4 & 0,35 & 0,4 & 0,25 & 4,05 & $\begin{array}{c}\text { Vulnerable } \\
1977\end{array}$ \\
752 & 138 & 4 & 4 & 3 & 0,35 & 0,4 & 0,25 & 3,75 & Vulnerable \\
752 & 1 & 10 & 2 & 3 & 5 & 0,35 & 0,4 & 0,25 & 3,15 & Vulnerable \\
37 & 0 & 3 & 1 & 0 & 2 & 0,35 & 0,4 & 0,25 & 0 & - \\
4 & 0 & 0 & 5 & 0 & 0 & 0,35 & 0,4 & 0,25 & 0 & - \\
\hline
\end{tabular}

Table 8 shows the data sorted by the highest number of each category. Then the data is given a score based on a predetermined score table and weighting. After that, the weighting calculation is carried out and produces a value adjusted to the vulnerability class table. The results are that most of Sungai Serut sub-districts are classified as flood vulnerability areas with the vulnerability class being very vulnerable and vulnerable. The vulnerability cannot be classified in the 4th and 5th data because one of the data categories is worth 0 .

\section{Results}

After weighting and overlaying, a flood vulnerability analysis map of Sungai Serut was produced which is shown in Figure 11.

To create this map, a layout with adjusted scale and coordinates is required. The scale used is 35,000 with UTM/WSG 84 coordinates, and other map components such as legends, and cardinal directions are added. 


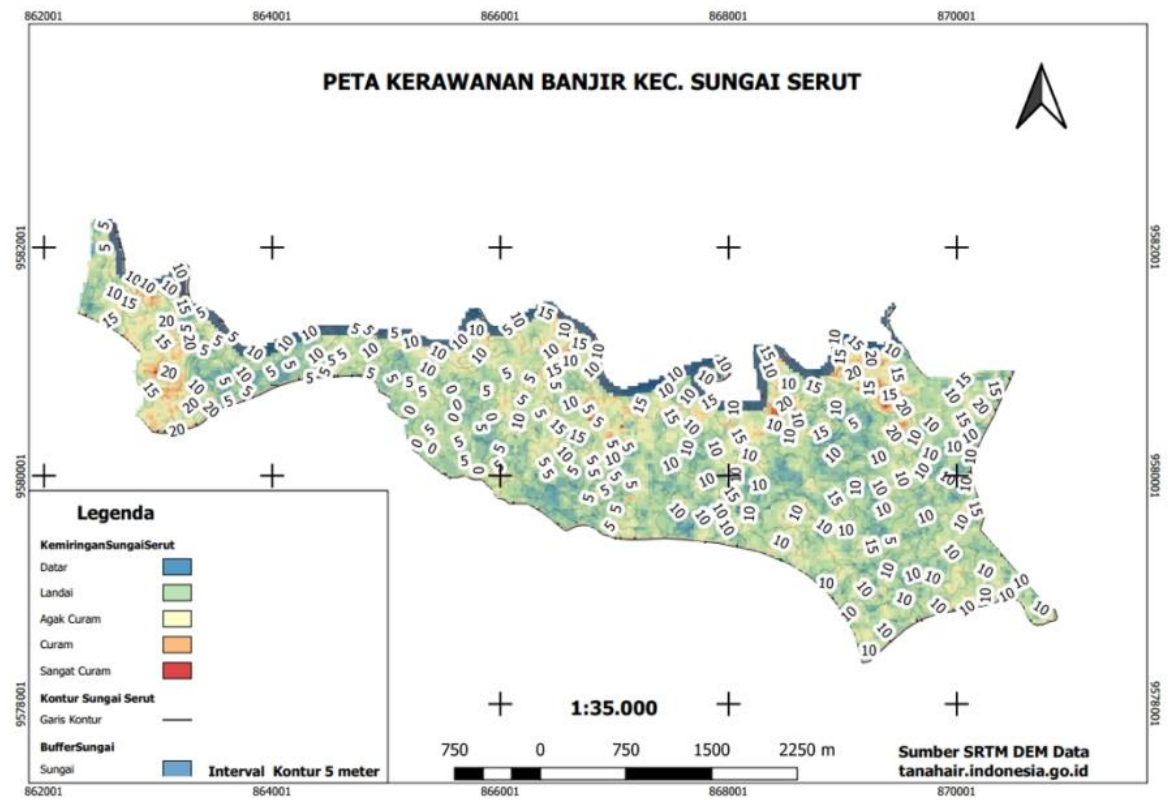

Figure 11. Map of flood vulnerability of Sungai Serut sub-district

Based on Figure 11, it is known that most of the areas in the Serut River are areas in the flood vulnerability category. This sub-district has a contour that tends to be sloping with an elevation level mostly below 20 meters above sea level. In addition, the thing that exacerbates the potential for flood vulnerability is the presence of rivers that run along the Sungai Serut sub-district.

\section{CONCLUSION}

The conclusion of this research are:

1. The condition of the Sungai Serut sub-district is an area with a flood vulnerability level of "Very Vulnerable" and "Vulnerable".

2. This study succeeded in knowing the level of flood vulnerability based on land slope, elevation, and distance from the river with Geographic Information Systems using the weighted overlay method.

3. The level of flood vulnerability in this study can be a reference for the government to determine steps and policies in overcoming the annual flood disaster in the Sungai Serut sub-district.

\section{ACKNOWLEDGEMENT}

Our gratitude goes to the Bengkulu University Research and Community Service Institute (LPPM), which has provided funding for this research through the 2020 Pembinaan research scheme.

\section{BIBLIOGRAPHY}

[1] L. Z. Mase, "Slope Stability and Erosion-Sedimentation Analyses Along Sub-watershed of Muara Bangkahulu River in Bengkulu City, Indonesia," E3S Web Conf., vol. 148, 2020.

[2] E. Ernawati, V. Arie, B. Andara, and R. Regen, "Web-GIS mapping for watershed and land cover area in Bengkulu," Sustinere J. Environ. Sustain., vol. 3, no. 3, 2019.

[3] P. M. Mather and M. Koch, "Environmental Geographical Information Systems: A Remote Sensing Perspective," in Computer Processing of Remotely-Sensed Images, John Wiley \& Sons, Ltd, 2011, pp. 325-375.

[4] G. Himbawan, "Penyebab Tetap Bermukimnya Masyarakat di Kawasan Rawan Banjir Kelurahan Tanjung Agung Kota Bengkulu.” UNIVERSITAS DIPONEGORO, 2010.

[5] I. U. Sikder, "Knowledge-based spatial decision support systems: An assessment of 
environmental adaptability of crops," Expert Syst. Appl., vol. 36, no. 3 PART 1, pp. 53415347, 2009.

[6] H. Hamdani, S. Permana, and A. Susetyaningsih, "Analisa daerah rawan banjir menggunakan aplikasi sistem informasi geografis (studi kasus pulau bangka)," J. Konstr., vol. 12, no. 1, 2014.

[7] F. W. Adininggar, A. Suprayogi, and A. P. Wijaya, "Pembuatan Peta Potensi Lahan Berdasarkan Kondisi Fisik Lahan Menggunakan Metode Weighted Overlay," J. Geod. Undip, vol. 5, no. 2, pp. 136-146, 2016.

[8] A. Lima et al., "Land use and land cover changes determine the spatial relationship between fire and deforestation in the Brazilian Amazon," Appl. Geogr., vol. 34, pp. 239-246, 2012.

[9] N. Tsutsumida and A. J. Comber, "Measures of spatio-temporal accuracy for time series land cover data," Int. J. Appl. Earth Obs. Geoinf., vol. 41, pp. 46-55, 2015.

[10] W. Komputer, Pemodelan SIG untuk Mitigasi Bencana. Elex Media Komputindo, 2015.

[11] T. P. E. Pratama, W. P. Prihadita, V. P. Yuliatama, S. P. Ramadhani, W. Safitri, and H. N. Syifa, "Analisis Index Overlay Untuk Pemetaan Kawasan Berpotensi Banjir di Gowa, Provinsi Sulawesi Selatan,” J. Geosains dan Remote Sens., vol. 1, no. 1, pp. 52-64, 2020.

[12] A. Putra, A. T. Ratnaningsih, and M. Ikhwan, "Pemetaan Daerah Rawan Kebakaran Hutan dan Lahan dengan Menggunakan SIstem Informasi Geografis (Studi Kasus: Kecamatan Bukit Batu, Kab. Bengkalis)," Wahana For. J. Kehutan., vol. 13, no. 1, pp. 55-63, 2018.

[13] E. Suherlan, "Zonasi Tingkat Kerentanan Banjir Kabupaten Bandung Menggunakan Sistim Informasi Geografis," Skripsi Fak. MIPA Inst. Pertan. Bogor, 2001.

[14] F. Angriani and R. Kumalawati, "Pemetaan Bahaya Banjir Kabupaten Hulu Sungai Tengah Provinsi Kalimantan Selatan," J. Spat. Wahana Komun. dan Inf. Geogr., vol. 16, no. 2, pp. 21-26, 2016.

[15] M. Sholahuddin, "SIG Untuk Memetakan Daerah Banjir Dengan Metode Skoring Dan Pembobotan (Studi Kasus Kabupaten Jepara),” Jepara: Udinus, 2014.

\section{BIOGRAPHY OF AUTHORS}

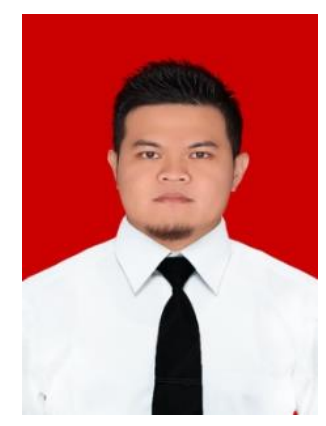

Ferzha Putra Utama, S.T., M.Eng. completed his undergraduate studies at the Informatics Engineering Study Program at University of Bengkulu in 2012. Then completed his master's education at the Department of Electrical Engineering and Information Technology, Gadjah Mada University, in 2015. He was currently serving as a lecturer at the Information Systems at University of Bengkulu since 2015. His current research is on GIS and UI/UX.

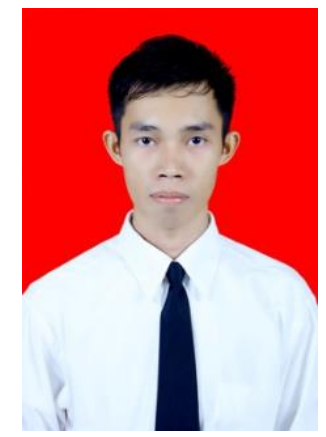

Yudi Setiawan, S.T., M.Eng. is an alumni of the Informatics Engineering Study Program at University of Bengkulu in 2012. Then completed his master's education at DTETI UGM in 2014. He is currently serving as a lecturer at the Information Systems at Bengkulu University since 2014. His current research is on Databases and Information Systems. 


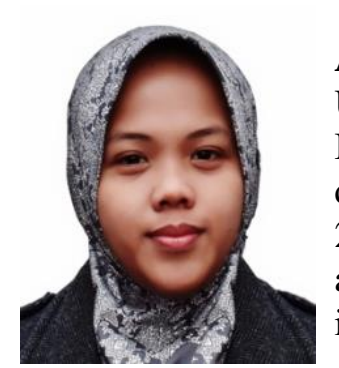

Arie Vatresia, S.T., M.T.I., Ph.D. is a graduate of Informatics Engineering at University of Bengkulu in 2007. She completed his master's degree in Information Technology, University of Indonesia in 2009. Then completed his doctoral education at Birmingham University, UK, in Computer Science in 2018. She was currently serving as Head of the Study Program of Informatics at Bengkulu University since 2019. The research being developed is currently in the fields of remote sensing, data mining, and GIS.

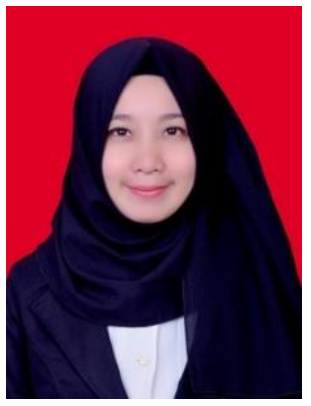

Julia Purnama Sari, S.T., M.Kom. completed her undergraduate study at the Informatics Engineering at University of Bengkulu in 2014. She then completed her master's education in Information Systems at Diponegoro University in 2017. She was currently serving as a lecturer at the Information Systems Study Program at University of Bengkulu since 2018. Her current research is on Information Systems. 